\title{
Aromatase activity in the rabbit blastocyst
}

\author{
R. C. Hoversland, S. K. Dey and D. C. Johnson \\ Departments of Obstetrics-Gynecology and Physiology, \\ Ralph L. Smith Research Center, University of Kansas Medical Center, \\ Kansas City, Kansas 66103, U.S.A.
}

\begin{abstract}
Summary. Rabbit blastocysts were homogenized by sonication, and centrifuged at $105000 \mathrm{~g}$ for $60 \mathrm{~min}$. The pellet was resuspended and incubated in phosphate buffer containing $\left[1 \beta-{ }^{3} \mathrm{H}\right]$ testosterone and a NADPH generating system. The amount of ${ }^{3} \mathrm{H}_{2} \mathrm{O}$ produced was determined by liquid scintillation counting. Enzyme activity was calculated, after subtracting blank values obtained with boiled embryos, and expressed as pg testosterone aromatized per embryo per hour. Aromatase activity was undetectable to low on Day 5 and increased on Day 6 of pregnancy. There was a 10-fold increase in activity in Day-6 embryos cultured for $24 \mathrm{~h}$, with a further 6-fold increase in activity in Day-6 embryos cultured for $48 \mathrm{~h}$. The enzyme had an apparent $K_{\mathrm{m}}$ of $0.77 \mu \mathrm{M}$ and was completely inhibited by an aromatase inhibitor. The results clearly indicate that the rabbit blastocyst has an increasing capacity for aromatization of testosterone at about the time of implantation.
\end{abstract}

\section{Introduction}

Synthesis and metabolism of steroids by preimplantation mammalian blastocysts remains a controversial issue (Dickmann, Dey \& Sen Gupta, 1976; Sauer, 1979; Gadsby, Heap \& Burton, 1980). The main points that emerge from several studies include: (1) the conceptual validity of steroidogenesis in rodent blastocysts still awaits biochemical evidence (Sherman \& Atienza, 1977), (2) biochemical evidence of steroidogenesis in pig blastocysts is convincing (Gadsby et al., 1980), and (3) biochemical evidence in favour of, as well as against, steroidogenesis in the rabbit blastocyst makes the issue confusing (George \& Wilson, 1978; Singh \& Booth, 1978; Bleau, 1981).

In view of the conflicting evidence in the literature, further studies are needed to determine the limits and the capacity of rabbit blastocysts to synthesize and metabolize steroids. All of the biochemical studies used so far involved conventional techniques of separation of steroids by chromatography or measuring the products by radioimmunoassay. In the present investigation, an attempt has been made to measure aromatase activity in rabbit blastocysts by the use of a tritium exchange assay technique.

\section{Preparation of tissue}

\section{Materials and Methods}

New Zealand white rabbits were induced to superovulate (Mukherjee, Dey, Sen Gupta, Ramadoss \& Dickmann, 1978) and blastocysts were recovered on Days 5 and 6 of pregnancy (120 and $144 \mathrm{~h}$ post coitum). In addition, Day 6 blastocysts were cultured for 24 and $48 \mathrm{~h}$ in TC-199 medium supplemented with crystalline bovine serum albumin (Sigma, St Louis, 
Missouri) and antibiotics under an atmosphere of $90 \%$ nitrogen, $5 \%$ carbon dioxide, and $5 \%$ oxygen at $37^{\circ} \mathrm{C}$ (Mukherjee et al., 1978) in order to obtain embryonic ages equivalent to Day 7 or 8 of pregnancy. At the end of the incubation the medium was removed with a pipette and the embryos were frozen in a minimum of fluid; they were stored at $-80^{\circ} \mathrm{C}$ until assayed. After thawing, blastocysts were homogenized in assay buffer using a micro-ultrasonic cell disrupter with a $3 / 32$ in. $(2.5 \mathrm{~mm})$ tip and a power of $541 \mathrm{~W} /$ inch (Kontes, Evanston, Illinois) and the homogenate centrifuged at $105000 \mathrm{~g}$ for $60 \mathrm{~min}$ at $4{ }^{\circ} \mathrm{C}$. The pellet was resuspended in 0.15 M-phosphate buffer (pH 7.4) and assayed for aromatase activity.

\section{Assay procedure}

The assay is based on the liberation of ${ }^{3} \mathrm{H}_{2} \mathrm{O}$ from $\left[1 \beta-{ }^{3} \mathrm{H}\right]$ testosterone by aromatase activity (Thompson \& Sitteri, 1974). $\left[1 \beta, 2 \beta-{ }^{3} \mathrm{H}\right]$ testosterone (sp. act. $250 \mu \mathrm{Ci} / \mathrm{nmol}$ ) was purchased from New England Nuclear (Boston, Massachusetts). The labile $2 \beta-{ }^{3} \mathrm{H}$ was removed by enolization in hot alcoholic KOH (Osawa \& Spaeth, 1971). Column chromatography with Sephadex LH-20 was used to purify the testosterone after the enolization procedure.

The reaction mixture, in a final volume of $200 \mu \mathrm{l} 0.15$ M-phosphate buffer $(\mathrm{pH} \mathrm{7.6),}$ contained $0.5 \mathrm{nmol}$ testosterone, $0.02 \mu \mathrm{mol}$ NADP, $0.1 \mu \mathrm{mol}$ glucose 6-phosphate, 0.02 i.u. glucose 6-phosphate dehydrogenase (Sigma), $0.04 \mu \mathrm{mol} \mathrm{MgCl}_{2}$ and the blastocyst extract. The incubation was run in $15 \times 75 \mathrm{~mm}$ polyethylene tubes for $60 \mathrm{~min}$ at $37^{\circ} \mathrm{C}$ in a Dubnoff metabolic shaking bath. The reaction was stopped by the addition of $400 \mu \mathrm{l}$ cold distilled water and a $4 \mathrm{mg}$ pellet of dextran-coated charcoal (Reflex Industries, North Hollywood, California). After centrifugation $(1000 \mathrm{~g}, 15 \mathrm{~min})$, the supernatant fluid was transferred to $16 \times 150 \mathrm{~mm}$ disposable glass tubes and distilled at $40^{\circ} \mathrm{C}$ under reduced pressure. The distilled water was collected in a $10 \times 75 \mathrm{~mm}$ disposable glass tube which was placed in a solid $\mathrm{CO}_{2}$-acetone bath. A sample of the distillate $(400 \mu \mathrm{l})$ was added to $5 \mathrm{ml}$ scintillation fluid (3a70, Research Products International Corp., Elk Grove, Illinois) and counted in a liquid scintillation counter with a $60 \%$ efficiency for tritium to determine the amount of ${ }^{3} \mathrm{H}_{2} \mathrm{O}$ produced as a result of aromatase activity. The aromatization of less than $30 \mathrm{pg}$ testosterone results in a measurable amount of ${ }^{3} \mathrm{H}_{2} \mathrm{O}$. Enzyme activity was calculated, after subtracting blank values obtained with boiled embryos, and expressed as $\mathrm{pg}$ testosterone aromatized per embryo per hour.

In a second study rabbit embryos were sonicated and centrifuged as described above. After reconstitution in phosphate buffer, aliquot quantities were assayed for aromatase activity as previously described; the testosterone concentrations were $1 \cdot 25,2 \cdot 5,5 \cdot 0,10 \cdot 0,20 \cdot 0$, and $40 \cdot 0$ $\mu \mathrm{M}$. At the end of the incubations, each sample was extracted with $2 \mathrm{ml}$ freshly opened diethyl ether. The aqueous phase was distilled to determine the amount of testosterone consumed while the ether phase was taken to dryness, redissolved and applied to a $30 \times 0.6 \mathrm{~cm}$ column of Sephadex LH-20. The column was eluted with benzene:methanol $(95: 5 \mathrm{v} / \mathrm{v})$ to separate oestradiol- $17 \beta$ from the $\left[{ }^{3} \mathrm{H}\right]$ testosterone substrate. The fractions with oestradiol were taken to dryness in a vacuum evaporator (Buchler Instruments, Fort Lee, New Jersey) and redissolved in methanol. The oestradiol content was determined by radioimmunoassay using unlabelled oestradiol-17 $\beta$ (Sigma) as the standard and $\left[2,4,6,7-{ }^{3} \mathrm{H}(\mathrm{N})\right]$ oestradiol- $17 \beta$ (sp. act. $90 \mathrm{Ci} / \mathrm{mmol}$; New England Nuclear) as the tracer. The anti-oestradiol antibody was prepared and characterized by Exley, Johnson \& Dean (1971). Complete details of the assay procedure have been published (Sashida \& Johnson, 1976).

In a third study, embryos that had been collected on Day 6 were cultured in the absence or the presence of 4-hydroxyandrostenedione, an inhibitor of aromatase activity (Brodie, Schwarzel $\&$ Brodie, 1976). This was repeated twice using concentrations of 25.0 and $50.0 \mathrm{nmol} / \mathrm{ml}$ in the culture media. After $48 \mathrm{~h}$ the embryos were rinsed and homogenized. One half of the $105000 \mathrm{~g}$ pellet was assayed for aromatase activity as indicated above and the other half was assayed with $10 \mathrm{nmol}$ 4-hydroxyandrostenedione added to the reaction mixture. 


\section{Results}

The aromatase activity was detectable in only one batch of Day 5 blastocysts (Table 1); radioactivity of the ${ }^{3} \mathrm{H}_{2} \mathrm{O}$ produced in the reaction was more than two standard deviations from the mean activity for blank tubes. The enzyme activity increased by Day 6 and was readily measurable in each of the four batches of blastocysts examined. Aromatase activity increased about 10 -fold during a $24 \mathrm{~h}$ incubation of Day 6 blastocysts and another 7 -fold increase was observed with an additional $24 \mathrm{~h}$ of incubation.

The aromatase activity of Day 6 embryo homogenates incubated for $1 \mathrm{~h}$ with increasing concentrations of tritiated testosterone is shown in Text-fig. 1. The apparent $K_{\mathrm{m}}$ of the blastocyst enzyme is $0.77 \mu \mathrm{M}$. If 4 -hydroxyandrostenedione was included in the reaction mixture, no

Table 1. Aromatase activity in rabbit blastocysts

\begin{tabular}{ccccc}
\hline Group & $\begin{array}{c}\text { No. of } \\
\text { exps }\end{array}$ & $\begin{array}{c}\text { No. of } \\
\text { blastocysts/ } \\
\text { exp. }\end{array}$ & $\begin{array}{c}\text { Age of } \\
\text { embryos } \\
\text { (days) }\end{array}$ & $\begin{array}{c}\text { Aromatase activity } \\
\text { (pg substrate consumed/embryo h }\end{array}{ }^{-1}$ ) \\
\hline 1 & 1 & 155 & 5 & $0 \cdot 35^{*}$ \\
2 & 4 & $48-177$ & 6 & $5 \cdot 9 \pm 3.8$ \\
3 & 4 & $26-109$ & $6 \dagger$ & $60 \cdot 6 \pm 28 \cdot 6$ \\
4 & 3 & $12-44$ & $6 \ddagger$ & $417 \pm 187$ \\
\hline
\end{tabular}

Values are mean \pm s.e.m.

* Activity was undetected in another experiment with 93 embryos.

$\dagger$ Day 6 blastocysts cultured for $24 \mathrm{~h}$.

$\ddagger$ Day 6 blastocysts cultured for $48 \mathrm{~h}$.

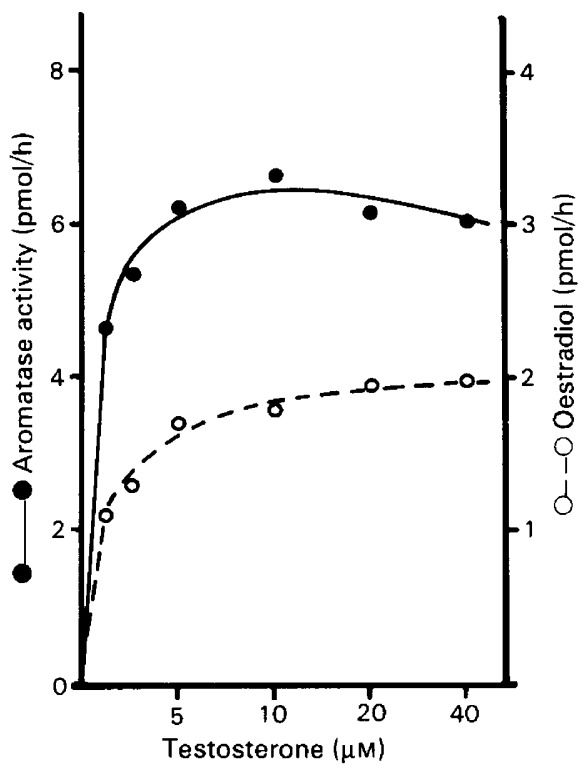

Text-fig. 1. The effect of testosterone concentration on aromatase activity in the rabbit blastocyst. Day 6 rabbit embryos $(N=44)$ that had been cultured for $48 \mathrm{~h}$ were sonicated and then centrifuged for $60 \mathrm{~min}$ at $105000 \mathrm{~g}$. The pellet was resuspended in $700 \mu \mathrm{l}$ buffer. Samples $(100 \mu \mathrm{l})$ were incubated with various concentrations of $\left[1 \beta-{ }^{3} \mathrm{H}\right]$ testosterone and the aromatase activity was determined by the tritium exchange method. The amount of immunoreactive oestradiol-17 $\beta$ formed was determined by radioimmunoassay following chromatographic separation of oestradiol from testosterone. 
enzyme activity was obtained. In addition, Day 6 blastocysts which had been incubated for $48 \mathrm{~h}$ in a medium containing the androgen had no detectable aromatase activity.

The radioimmunoassay of oestradiol in the reaction mixture for the aromatase assay indicated that $27.6 \pm 0.01 \%(n=6)$ of the aromatized testosterone was recoverable as oestradiol.

\section{Discussion}

The results of our present investigation clearly demonstrate that the rabbit blastocyst has the capacity to aromatize androgen beginning at about the time of implantation, and that this activity increases with age of the embryo. Our results confirm the findings of George \& Wilson (1978) who detected oestradiol formation from testosterone in blastocysts by conventional chromatographic methods. However, George \& Wilson (1978) were not able to detect aromatase activity in Day 5 or Day 6 embryos; we have now demonstrated activity in all Day 6 and in some Day 5 blastocysts. Considerable variability between batches of embryos was found. While differences between assays of enzymes are expected, some of the variability could be due to the differences in size of the blastocysts even though they were of the same age. Attempts to remove some of the variability by expressing the results in terms of protein were abandoned because the blastocysts can accumulate protein from the medium.

The column chromatography and radioimmunoassay of the reaction products indicated that about $28 \%$ of the aromatized testosterone was oestradiol-17 $\beta$. However, several oestrogenic steroids other than oestradiol could be formed by the blastocyst as a result of aromatization, and their determination is currently under investigation. Singh \& Booth (1978) detected considerable $17 \beta$-hydroxysteroid oxidoreductase activity in Day 6 embryos. Therefore, some of the oestradiol produced in our assays would be expected to be converted to oestrone, but this would not be detected by our radioimmunoassay procedure.

Which of the enzymes required for steroidogenesis are present in the rabbit blastocyst is presently unclear (George \& Wilson, 1978; Singh \& Booth, 1978; Bleau, 1981). Neither Singh \&

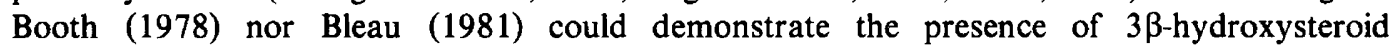
dehydrogenase activity in the Day 6 rabbit blastocyst. Furthermore, Singh \& Booth (1978) could not detect the production of oestrogen from progesterone or androgen by the blastocysts. Whether this failure to find aromatase activity is a consequence of using too few embryos in the reaction mixture, an inadequate concentration of substrate or other factors is unknown. The apparent $K_{\mathrm{m}}$ of the blastocyst aromatase using testosterone $(0.77 \mu \mathrm{M})$ is similar to that reported for the human placental enzyme (Gibb \& Lavoie, 1980) but well above the concentration used by Singh \& Booth (1978). A failure to use saturating concentrations of substrates may be true for several steroidogenic studies with blastocysts. In addition, the use of large numbers of embryos appears to be required in order to obtain measurable amounts of steroid production.

Although the rabbit blastocyst has considerable aromatase activity on Day 6 and thereafter, we do not know whether they synthesize oestrogen in vivo. The physiological significance of any oestrogen produced by the embryo, or that which is accumulated by the blastocyst from the mother (Singh \& Booth, 1978), is also unknown. Oestrogen produced by the pig blastocyst has been related to maternal recognition of the presence of the conceptus and thereby maintenance of the corpus luteum (Gadsby et al., 1980). In the rabbit, implantation occurs in the absence of maternal oestrogen (Kwun \& Emmens, 1974). Further studies will be necessary in order to determine whether oestrogen from the blastocyst has any role in maternal recognition of pregnancy or implantation.

We thank Cheri Cox and Murriel Wagoner for excellent technical assistance. This research was supported by grant No. HD-12122 from NICHD. R.C.H. was a recipient of a NRS award HD-05838-01 from NICHD. 


\section{References}

Bleau, G. (1981) Failure to detect $\Delta 5-3 \beta$-hydroxysteroid oxidoreductase activity in the preimplantation rabbit embryo. Steroids 37, 121-132.

Brodie, A.M., Schwarzel, W.C. \& Brodie, H.J. (1976) Studies on the mechanism of estrogen biosynthesis in the rat ovary -I. J. Steroid Biochem. 7, 787-793.

Dickmann, Z., Dey, S.K. \& Sen Gupta, J. (1976) A new concept: control of early pregnancy by steroid hormones originating in the preimplantation embryo. Vitams Horm. 34, 215-242.

Exley, D., Johnson, N.W. \& Dean, P.D.G. (1971) Antisera highly specific for $17 \beta$-estradiol. Steroids 18, 605-620.

Gadsby, J.E., Heap, R.B. \& Burton, R.D. (1980) Oestrogen production by blastocyst and embryonic tissue of various species. J. Reprod. Fert. 60, 409-417.

George, F.W. \& Wilson, J.D. (1978) Estrogen formation in the early rabbit embryo. Science, N.Y. 199, 200-201.

Gibb, W. \& Lavoie, J. (1980) Substrate specificity of the placental microsomal aromatase. Steroids 36, 507519.

Kwun, J.K. \& Emmens, C.W. (1974) Hormonal requirements for implantation and pregnancy in the ovariectomized rabbit. Aust. J. biol. Sci. 27, 275-283.
Mukherjee, A., Dey, S.K., Sen Gupta, J., Ramadoss, C.S. \& Dickmann, Z. (1978) Regulatory enzymes of carbohydrate and energy metabolism in the rabbit blastocyst. J. Reprod. Fert. 53, 77-80.

Osawa, Y. \& Spaeth, D.G. (1971) Estrogen biosynthesis. Stereo-specific distribution of tritium in testosterone1,2,-t. Biochemistry, N.Y. 10, 66-71.

Sashida, T. \& Johnson, D.C. (1976) Stimulation of the estrogen synthesizing system of the immature rat ovary by exogenous and endogenous gonadotropins. Steroids 27, 469-479.

Sauer, M.J. (1979) Hormone involvement in the establishment of pregnancy. J. Reprod. Fert. 56, 725-743.

Sherman, M.I. \& Atienza, S.B. (1977) Production and metabolism of progesterone and androstenedione by cultured mouse blastocysts. Biol. Reprod. 16, 190199.

Singh, M.M. \& Booth, W.D. (1978) Studies on the metabolism of neutral steroids by preimplantation rabbit blastocysts in vitro and the origin of blastocyst oestrogen. J. Reprod. Fert. 53, 297-304.

Thompson, E.A. \& Sitteri, P.K. (1974) Utilization of oxygen and reduced nicotinamide adenine dinucleotide phosphate by human placental microsomes during aromatization of androstenedione. J. biol. Chem. 249, 5364-5372.

Received 1 December 1981 